\title{
6 CORES AND DEFINITIONS: Building the Cognitive Legitimacy of the Information Systems Discipline Across the Atlantic
}

\author{
Frantz Rowe \\ University of Nantes \\ Duane P. Truex III \\ Florida International University and \\ Georgia State University \\ Lynette Kvasny \\ Pennsylvania State University
}

\begin{abstract}
The issue of the legitimacy of Information Systems is important for researchers in this field because other disciplines have begun to lay claim to research topics often thought to belong to the domain of IS research, and the field itself is under challenge in academic intuitions around the world (Avison 2002). Benbasat and Zmud's (2003) opinion is that IS has gained socio-political legitimacy but not cognitive legitimacy in large measure because the object of study in much IS research is not clearly delineated. In part, they are defining a disciplinary boundary issue and beginning to define criteria by which our field may be distinguished from reference disciplines or other related disciplines. Therefore, to gain more cognitive legitimacy, a clearer understanding of what we mean by "an information system" and of the central issues driving its creation and use is needed if it is at the core of that which we study. This paper advances that discourse by examining the role of a handful of French scholars, many of whom are not well known out of French academic circles, but whose thoughts on the issue are useful in furthering the debate on the ontological grounding of our field.
\end{abstract}

Keywords: Cores of the discipline, ontology, information system definition, IT enabled solutions, social theories 


\section{INTRODUCTION}

This paper begins from the position that a general recognition and broad acceptance of a set of underlying core issues differentiating our field is an important element in asserting the legitimacy of Information Systems as a discipline. Is it important to seek agreement as to the core constructs underpinning our discipline? Stated more precisely, why is it necessary to constantly seek to justify our own existence?

This is not a new question. More than a decade ago Banville and Landry (1989) questioned if the field might be disciplined, other scholars examined the development of distinctiveness in the field using various bibliometric analyses to see if IS as a field had made a break from our own reference disciplines (Culnan 1986; Culnan and Swanson 1986). Still other scholars considered if or how the field might fare with a diffuse pluralistic core wherein many flowers were allowed to bloom (Robey 1996). More recently, scholars have been considering the lack of theorizing about technology in IS and ICT research (Orlikowski and Iacono 2001; Sawyer and Chen 2002), while others have revisited the issue of whether we have become our own, unique, reference discipline (Alter 2003; Baskerville and Myers 2002).

Recent threads on ISWorld attest to more recent challenges being made to the continuance, structure, and integrity of IS programs worldwide. Influential scholars and journal editors suggest that there is serious disagreement about the efficacy in the field and that the field is in crisis (Karahanna et al. 2003; Hirschheim and Klein 2003; Weber 2003). Harvard Business Review published an article that taps into a wellspring of resentment against the enterprise IS function and created a firestorm in the popular press (Carr 2003).

So, while there may not yet be a consensus as to the nature of the problem, there seems to be continuing concern that, at the core, there may be something amorphous and ill defined about our field. Benbasat and Zmud (2003) lament the ambiguity of the core or our field and argue that the field lacks a cognitive legitimacy as a result. The general notion is that identifying a core to the discipline helps explain that which is unique about the discipline, thus differentiating it from reference fields or other functional disciplines and helping to establish legitimacy. Albert and Whetten (1985) argue that, to claim legitimacy as a separate field of endeavor, a discipline must establish (1) the central character it is studying, (2) its distinctiveness, and (3) its temporal continuity. We return to these three points in section two following. But first we address the question of why we should be concerned with establishing commonly accepted notions about the core of our discipline.

In our view there are political, economic, and scholarly reasons for addressing the issue of core notions of the field. The first, or political, argument holds that since faculty representing other disciplines sit on tenure and promotion committees and serve on curricular committees and other university-wide bodies that decide upon resource allocation, it is wise to relate to them in ways common to their own discipline. Since the sister functions-marketing, finance, economics, management, accounting, and the like-have a commonly accepted core around which their own disciplinary work occurs, it is appropriate that we do the same.

Gordon Davis has developed this idea, saying that ours is an applied field tied strongly to the organizational functions of information systems and information manage- 
ment, and that the vitality of our academic field is tied closely to the vitality and boundaries of the IS function (Karahanna et al. 2003). Within that function, there exist specialized skills and specialized knowledge that help differentiate the field; dealing with these core issues defines the purview of the function and hence the academic discipline. Davis then generalizes back to our sister academic functions in suggesting that there are "strongly shared activities" at the boundary of these functions. These are the activities where IS interfaces with and become key tools to another discipline such as marketing or production. At these interfaces are opportunities for shared research and for communication about core issues. But the boundaries, clearly differentiating our research concerns from other disciplines mark a territory that is uniquely our own.

The second, or economic, reason is closely associated with the political argument and is manifest in the concerns over declining enrollments in academic IS programs across the globe. Are structural changes in IS development and operations putting the field itself at risk? Will there be places for our graduates to work? This question seems to motivate students in choosing majors. We need to respect their concern and learn what the economic consequences may be for changing demand patterns for IS graduates. A clear understanding of and ability to articulate the core of the field may help isolate us from concerns that the field has died because programming has moved off shore, or infrastructures are embedded in enterprise-level applications, or other cyclical changes arising from social and technical change. At the core there should be more than a single technology, method, or research concern.

The third, or scholarly, rationale is more complex, and is being considered on a number of fronts. Benbasat and Zmud argue that IS has gained socio-political legitimacy but not cognitive legitimacy in large measure because the object of study in much IS research is not clearly delineated. They define a boundary condition in which they suggest a kind of delineation by proximity to actual systems artifacts. Hirschheim and Klein (2003) argue that to save the field we need to take corrective or transformative action to solve communications problems within the scholarly community, and between the field and the practitioner community with whom we run the risk of being considered irrelevant. To these authors, it becomes important to reach an agreement of the existence and organization of a common body of knowledge central to the field. Agreement with or acceptance of this common body of knowledge then becomes a criterion of membership in the field (Hirschheim and Klein 2003). For some, this is an issue of language. The late essayist Neil Postman (1988) said that knowledge of any discipline required defining, learning, and managing the language of that discipline. Steven Alter (2003), addressing the communications gaps described by Hirschheim and Klein, suggests that the field needs a better way to talk about itself and the core objects of interest. Like others, he argues "that in order for a business professional to understand an information system it is necessary to understand the work system that the information system serves." In other words, Alter is struggling with defining a means where the field might have a kind of "Sysperanto" or useful language for describing systems and other central concepts to the discipline. His notion of a useful language includes providing practical help in identifying, observing, and conceptualizing information systems and their operations and place in organizational contexts.

It should be noted that a few other scholars suggest that there is no need to define a core of the field, arguing rather that we speak via the systems we build and install 
(Karahanna et al. 2003). Yet even this position entails core assumptions, even if unexpressed, about a core, and it is one in which the technical artefact is itself central.

In this paper we do not posit a single core, rather that there may be a core set of issues. We wish to make a contribution to that discourse itself by introducing and illustrating how French research in IS, philosophy, and sociology can advance the debate on cognitive legitimacy of IS. Specifically we address the central notion that to achieve higher cognitive legitimacy for the IS discipline, we must establish the central character of what we are studying; its distinctiveness and possibly its temporal continuity. This manuscript examines how French authors help consider the question of the central character of our field and then briefly discusses the themes of distinctiveness and temporal continuity, leaving a fuller treatment of those themes for a later paper.

The balance of this paper proceeds as follows: Section 2 examines three themes that warrant claims to a field's intellectual legitimacy. Section 3 addresses the question of an ontology raised inevitably by considering the nature of the IS as an object of study. The fourth section examines how five French scholars characterize or cause the IS object to be characterized. Section 5 summarizes and suggests a plan for further research.

\section{THREE THEMES SUPPORTING THE FIELD'S CLAIMS TO LEGITIMACY}

We now return to the question ofhow a field might solidify claims to its legitimacy by considering the argument by Albert and Whetten (1985) that we must first establish the central character we study, then we must establish our field's distinctiveness and finally achieve a measure of temporal continuity.

\subsection{Theme 1: The Field's Central Character}

One of the central claims to IS disciplinary distinctiveness is the focus upon the control and evaluation of IT in organizations, or more precisely what Benbasat and Zmud (2003) call "IT-enabled solutions." This claim is supported by a study examining 1,018 articles in major English and French publication venues from 1977-2001. ${ }^{1}$ This study identifies six major problem areas addressed by the papers in these publication years and venues. Those are (1) gestion stratégique (strategic management), (2) économie, divers (various economic issues), (3) conception (design), (4) gestion des projects (project management), (5) evaluation (evaluation), and (6) animation (or roughly, appropriation and change management (Desq et al 2002). Their study illustrates how for both English and French authors the issue of evaluation is an important focus

${ }^{1}$ Those venues included from the Anglophone world two relatively older venues-MIS Quarterly and the proceedings of the International Conference on Information Systems (1980 onward) - and relative Francophone newcomers, two French journals, Technologies Information et Société (TIS) (f. 1996) and Systémes d'Information et Management (f. 1996), and two conferences.l'Association Information et Mangement (AIM) (f. 1997) and les journées nationals des IAE(f. 1984) 


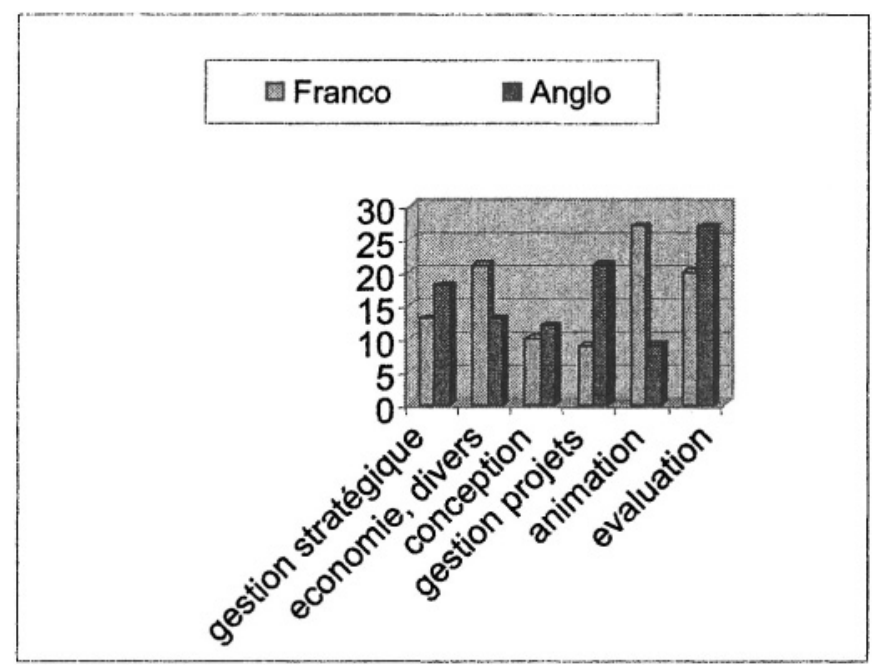

Figure 1. Problems

and that a generalized notion of control is the dominant theme of 25 years of research (see Figure 1). One result stands clear: the theme of evaluation of info systems represents 25 percent of the work (Shapiro 1998). The more general theme of control (animation, evaluation, and personnel management) dominates the field with 45 percent, far ahead of design (28 percent and strategy 23 percent.

The theme of evaluation was found to be a relatively stable construct over time even though historically the issue was analyzed at the individual level, whereas in recent years it is applied more at the organizational or interorganizational level. In recent work, the dependent variables are more likely to address potentials (e.g., competitive advantage, flexibility) than actual results.

In this manuscript, we use the concepts of control and evaluation in a slightly broader sense. We view evaluation as a process that occurs at the various stages of information systems evolution (i.e., design, use, and impacts; Soh and Markus 1995). The later concern includes organizational, managerial, and other stakeholder impacts. In the domain of IS management, Willcocks and Lester (1993) say that

evaluation is about establishing by quantitative and/or qualitative means the worth of IS to the organization. Evaluation brings in to play notions of costs, benefits, risk and value. It also implies an organizational process by which these factors are accessed, whether formally or informally.

We like this definition because it identifies how evaluation is undertaken in any organizational setting as a matter of course in routine interfacing with an information system. The evaluation process is done in both formal and informal modes by managers as well as by other organizational stakeholders. So, given the embedded nature of IS artifacts in human organizational settings, the process of evaluation requires both managerial and technological evaluation tools and methods. 
IS design methods also incorporate procedures for managerial control and technical evaluation, taking into account goals, anticipating some of the impacts, and finally dealing with the specification methods for information needs (Purao et al. 2002). In the realm of system use, control and evaluation occur for two main reasons: to anticipate or learn exactly how many people will really use the system, and to understand how (or if) they will appropriate it. The situated use of the IS often implies some measure of transformation from use anticipated by the system's designer and builder's to that employed at the user level. Thus one other meaning of evaluation is concerned with diffusion and infusion issues (Saga and Zmud 1994). This lag between conception and the adoption in organizational settings means that it is only expost to system design, development, and deployment, and typically much later after the appropriation in the organization that we can assess the net economic benefits of the system. In fact it has been suggested that it is only after competitors have made (or not made) similar investments that we can assess the net economic benefits of the system. The context of evaluation is not only organizational, but includes the competitive structure of the industry in which the firm is located (Soh and Markus 1995).

\subsection{Theme 2: Distinctiveness of the Field}

Following from the claim above, that evaluation and control are issues at the core of IS research, one of the key claims to the distinctiveness of our discipline lies in the way we assess IT-based systems. In this regard, IS research is a big tent allowing many approaches to this process.

Nevertheless our discipline is distinct in the way it helps develop evaluation methods at each stage of evolution of the IT artefact (proposal, development, implementation, post-implementation, routine operations (Willcocks and Lester 1993), and at the same time takes into account the role, importance, and interaction of social actors, the structures of organizations, strategies, and tasks among a host of other issues (Benbasat and Zmud 2003; Marciniak and Rowe 1997).

\subsection{Theme 3: The Field's Temporal Continuity}

Temporal continuity deals with the relative maturity and consistency of views in a field. It is more difficult to argue our field's legitimacy on this dimension because of the relative youth of IS and because the field is very dependent on dynamic technological innovations (Reix and Rowe 2002). Previous attempts to delineate the evolving independence of our field have focused on citation analyses of IS papers, examining the degree to which they cite authors and sources in reference disciplines versus citing other IS works (Culnan 1986; Culnan and Swanson 1986). More recently, we have seen claims that the growing continuity of distinctively IS research provide evidence of a temporal continuity to the field (Baskerville and Myers 2002). The notion of process or organizational control has been a part of this literature almost from the beginning (cf. the "Minnesota experiments") and remains key in the literature to this day. As discussed above, the study of 25 years of IS research suggests a reasonably constant set of issue. This provides evidence of the temporal continuity needed in legitimizing a field. 


\section{THE DEFINITION OF AN INFORMATION SYSTEM AS AN OBJECT OF STUDY: THE QUESTIONS OF AN ONTOLOGY}

Following from these observations, it is our contention that, in order to achieve higher cognitive legitimacy, our own discipline must clearly articulate the core concepts it is using. This is not a trivial exercise because it is both raises ontological questions and presents the political challenges of any definitional issue. Postman (1988) reasons that the knowledge of any discipline is defined by knowledge of the language of the discipline. This explains why definitional battles are prominent in many disciplines. Terminological development itself is a convoluted process. In our own field, this point is well illustrated by Robert Gray's (2003) historical review of the distinction between the commonly used and accepted terms data and information. Thus if we claim that we are principally dealing with issues of control in the development of IT-based solutions, we are left with the question of what do we mean by IT-enabled solutions. What do we mean by and define as the central object of our interest and study in the field? What is an IT-enabled solution? What is an information system? Once we get a clear picture of these questions, then we can better tackle larger questions, such as how do we conceptualize the IT artifact (Orlikowski and Iacono 2001; Sawyer and Chen 2002)?

This paper takes aim at this issue from the contributions made to this discourse by French IS researchers and sociologists who have influenced other IS researchers in and out of France. Defining an information system is an ontological issue. The discourse on ontologies is long and rich within the literature of the IFIP WG 8.2 community. However, because the term is now being used in very different ways within our own field, as for example between the so-called design community, the requirements engineering community, and the IS community, it is necessary to briefly explain our use of the term as well as where within the ontology discourse we place ourselves.

Ontology is the part of philosophy aimed at studying being as being. It can be centered on the fact of being (existentialism) or on the nature of being (essentialism). The relationship between essence and existence is the fundamental problem of any ontology. In IS, as in other disciplines, we can consider two different problems.

1. The building of an ontology — a problem that has been taken very seriously by many researchers in data base management and in IS development (Hirschheim et al. 1995). The challenge is to reduce the elements of an objective reality to a limited number of notions, as general as possible (see, for instance, the two-layered ontology of Parsons and Wand 2000) and to describe the structure of the universe from these notions and their relationships.

2. The ontology can be defined as the "exploitation of being of being structures and we would rather define metaphysics as the questioning of the existence of being" (Sartre 1943, pp. 358-359). Sarte also stated that, "In an ontology things take ontic attributes. But conscience can overcome the fact of being to the sense of being" ( $p$. 30).

Therefore, we could say that what IS scholars consider is the study of the information system in its intimate and deep nature, as opposed to its appearance or its 
attributes. Using Sartre's own words, we are dealing with the ontological or metaphysical problem as opposed to the ontic problem of an information system (the latter being considered as the ontological problem in software engineering).

This paper does not allow a full treatment of the ontological discourse nor does it allow for the identification of the full population of productive French IS academics nor ofFrench sociologists and philosophers who have influenced other (curiously often nonFrench) IS scholars. So in the balance of this paper, we will present a small, illustrative sample of French IS scholars and point to but three French sociologists (Crozier, Bourdieu, and Latour, the last two being well known to our community). As a set, we use these scholars to illustrate the question of how one may view the core of the IS research ontological debate from a French perspective.

\section{FRENCH SCHOLARS ON THE INFORMATION SYSTEM DEFINITION}

We now turn our attention to specific French IS scholars, some of whom are, regrettably, only occasionally available in English translation. Within this initial community we can find five conceptions of an information system arising from different positions on the ontological spectrum. This contradicts the idea that there is a single French ontological view of the IS core in contrast with say an American or German ontological view of an IS core. Those views expressed in the French IS literature are

- derived from a rationalist and software engineering viewpoint; the nature of an information system is a formal code and an artifact of a different nature than the socio-technical system it controls (social or natural)

- derived from general system theory; the nature of an information system is not different from that of the socio-technical system in which it is embedded

- derived from a pluralist view the nature of an information system is human and social

- derived from a critical sociologist view where structures are reinforced by culture and language and constrain more (Bourdieu) or less (Crozier) actions

- derived from a historical view of science and technology (Latour)

\subsection{Peaucelle and Rolland: Information Systems as a Codified Language_A Rationalist Software Engineering View}

The prevailing conceptualization comes from computer science and the software engineering literature. One of its leading figures, former IFIP 8.1 chair, Rolland wrote (1986)

An information system is an artefact, an artificial object, grafted on a natural object which can be an organization, an industrial process, an embarked command. It is designed for memorizing a set of images of the real object at different times in its life; these images must be accessed by partners of the organization for decision purposes in the best conditions. 
For Peaucelle (1981), translator of Davis and Olson's (1985) book, the notion of an information system is implicitly restricted to formal systems, those dealing with data according to specified rules (p. 8). He views an information system as a formal code and the outcome of an intersubjective process, one which has a unique and collective fixed meaning that is justified by organizational routines.

An information system is a communication language of the organization, build [sic] consciously by its members to represent, in a reliable and objective manner, rapidly and economically, some aspects of its activity, past or future. Sentences and words of this language are data and their signification comes from the rules of their making by men or machines. The representation mechanisms, special to this type of language, prove efficient in the routinization of organizations acts (pp. 24-25).

Peaucelle and Rolland share the view that an information system is an artefact (Weber 1987), in the first sense recalled by Alter (2003). Consequently, their nature is different from that of organizations which can be considered either as socio-technical systems with an important informal component (Peaucelle 1981), or as natural objects (Rolland 1986).

By their insistence on a possible objective coding and fixed meaning, information systems appears as the tool of rationalization of the organization. It aims at designating transactions and formal processes. It naturalizes the organization and derives from a realist ontology.

\subsection{LeMoigne and Melèse: The Appropriation of General Systems Theory and its Evolution Toward Constructivism}

LeMoigne is well known in France as one of the men who has adapted Von Bertralanffy's general systems theory (LeMoigne 1977) while also offering a strong criticism of the analytical and Cartesian method for designing information systems (LeMoigne 1996). He is also one of the first authors in France to write a book on information systems and not on data processing or "informatique de gestion," in which he concluded

the information system of an organization can and must only be in charge of one essential function, that of memorizing — collecting, storing and retrieving all information generated by its transactions with its environment and, incidentally, some others that members of the organization wish to share for some time (LeMoigne 1973, p. 195).

However, he has not explicitly proposed a formal definition of an information system. In one of his most well known contributions on this topic (LeMoigne 1986) first presented at the IFIP Conference in Toronto in 1977 with Maurice Landry, we can only find it in a figure (Landry and LeMoigne 1977). There they convey the idea that an 
organizational information system is the memorization system of the organization's information. His definition also constitutes both an intermediary and a regulation mechanism between the system of operations and the control system of the former cybernetics representation of the functioning of an organization. As such, we did not contemplate a revolution in terms of IS thinking that might call for abandoning Davis's (1974) definition of an information system, a definition that LeMoigne explicitly associates with a cybernetic view of the organization. Nevertheless, LeMoigne's view is that the goal of an information system cannot be the control of a rational norm (Dehaene 1992). More interestingly, LeMoigne criticizes the MIS paradigm for not doing justice to the generation and memorization of information processes. LeMoigne especially insists on these two problems: "The new paradigm of information systems must take into account the capacity of the organization to represent itself, its behaviors and its transformations and not anymore its capacity to control them" (1986, p. 27).

In fact, an organization is organizing itselfby its information processes, reciprocally in an auto-referential process (Wilensky 1983). Information systems inform the organization which forms (makes) them. The way information systems are constructed is, therefore, generated by the activities of the organization and by the data modeling, which are particular to each organization. Secondly, this representation must be appropriated and co-memorized by several actors (LeMoigne and Pascot 1979).

LeMoigne and his team were very influential in the French IS world both with academics and practitioners when they developed the MERISE design method. For his team, information systems modeling enriches the modeled reality, not only because it is incorporated in it and as such simplifies it, but because even if it were not incorporated in it, it potentially contains more diverse realities than what has been modeled (Tabourier 1986, p. 32). In view of his team, LeMoigne's golden triangle of intellectual debt is attributed to Morin, Piaget, and Simon (GRASCE 1999, p. 5). From an epistemological viewpoint, he openly declares himself to be a social constructivist. For him IS and many other kinds of engineering activity are social constructions and cannot be studied with positivist lenses.

LeMoigne (1996) refers to a remarkable theoretical essay by Jacques Mélèse, another advocate of the systems approach, where Mélèse (1979, p. 36) defines an information system as "the set of processes which, by exchange of significations, allow, globally and locally in the firm, consistency, equilibration, backup and innovation." Mélèse insists that relevant information is not only codified and formal, but is often informal and qualitative, and that each organizational unit has to represent itself and its environment and allow other units to do so (i.e., to set up an informational situation in a participative way).

As Mélèse added, "perceived information should be most interpretable and locally usable" (p. 37). For that matter, formal communication of codified information between units and levels should be limited, because of noise and distortion. Conversely, in each unit, informational learning and sense making should be developed. He finally added, "Make of all organizational level, places of information association and sense emerging" (p. 37). Therefore, we consider Melèse as an interpretivist, in the sense close to Karl Weick's characterization of the objects of research, but also a social constructivist (LeMoigne 1996, p. 131) who was strongly influenced by Beer, Morin, Piaget, and Bateson. 
What is important and common to both Melèse and LeMoigne is that to a certain extent they explicitly refuse to tackle the ontology of an information system even though we find the definition, cited above, in Melèse's work. The important point here is that, for them, an information system is a socio-technical system and one isomorphic to that of the organization. It is not just a management information system, but a socially constructed organizational information system (LeMoigne and Van Gigch 1990).

\subsection{Reix and Rowe: A Pluralist View-The Nature of an Information System Is Human and Social}

In their introduction to IS research, after a review of the history of the IS discipline and prominent definitions, Reix and Rowe (2002) offered the following definition: "A set of social actors who memorize and transform representations, via information technologies and operating modes " (p. 7). They founded their definition on previous work in IS as well as on Bourdieu and Crozier and argued that this definition is also the result of an eidetic reduction (Husserl 1950) and takes into account

- The fundamental human and social nature of any information system, by putting upfront the social actor. An information system is not just an abstract objective representation or the fixed outcome of intersubjectivity, but it always remains subject to interpretation, social games, and conflicts (Bourdieu 1980; Crozier and Friedberg 1977). This view contrasts with that of Lamb and Kling (2003). While both views agree upon the central role of the social actor, Lamb and Kling see the information system as a product and external representation of man's activity.

- The fundamental functions of memorizing (LeMoigne 1973) and transforming representations (LeMoigne 1990).

- The possibility of working with or without information technology and with or without some modus operandi (Bourdieu 1980).

The first point also appears as the logical outcome of the idea of information being constructed as meaningful for a user and needing interpretation (Gray 2003). If we talk about information system, it does not mean they exist out there, as external things; we are talking about an intellectual construct, which from a phenomenological viewpoint demands a human and social interpretation at some point. Moreover, this definition, with the second additional point, opens the possibility of considering activities such as cognitive processes, informal talks and the use of tacit knowledge, for instance in communities of practice, as phenomena linked to the concept (Michaux and Rowe 2004).

The fact of considering the concept as encompassing informal phenomena departs from the rationalist and empiricist position developed in software engineering. However, from an epistemological viewpoint, $\operatorname{Monod}(2002$, p. 44) considered this definition as reflecting a pluralist view. For him, in addition to its insistence on representation processes tending toward interpretivism, this definition also stresses social games tending toward the sociology of conflicts, while the technology supporting information processes and its operating modes tends toward a positivist view. The authors fully agree with Kallinikos (2002, p. 289) that "the formation of the premises governing the humantechnology interaction must be analyzed with reference to the constitutive properties of 
technology and the distinctive forms by which various technologies emerge as standing possibilities of one type or another," as it has been shown on empirical works (Rowe and Struck 1999).

\subsection{Bourdieu's Critical Realism and Influence on IS Scholars}

We see at least four reasons for using Bourdieu in Information Systems. First, as a sociologist of practice, he clearly distinguishes between opus operatum and modus operandi, between prescription and activity. Second, he expressly fought the language philosophers (Ricoeur, Austin, and Searle) for language is rarely performative in itself; it is the social status of the speaker which gives legitimacy and meaning to language propositions. Third, Bourdieu (1980) sharply criticizes the reductionism of most quantitative surveys. In his own work, he adopts and advocates for mixed methods to investigate social phenomenon. Finally, and above all, Bourdieu helps us think about control, power, and domination, which are at the heart of the first core of the IS discipline. In doing so, we can better theorize the practices of social actors.

For Bourdieu, societal structures are socially defined and maintained. They have great persistence and are very difficult to change. As such, they have enormous influence over human behavior. One objective of Bourdieu's theoretical framework is to uncover the buried organizational structures and mechanisms that are used to ensure the reproduction of social order. His framework helps us understand how changes arising from information technology may actually reinforce existing power structures and help perpetuate the social order. For Bourdieu, change (including technological change) is a self-regenerative mechanism required for the maintenance of stratified organizational hierarchies. So where, one the one hand, static structures can be figured out and conquered over time, on the other hand, changing structures keep actors offbalance, and thus lead them to apply familiar strategies in unfamiliar contexts, reinforcing old structures, behaviors, rules, and order. It is this reuse of learned dispositions (habitus) in new settings that make existing class positions self-sustaining.

Referring to Bourdieu, IS researchers examine the nature of those structures and the impact they have on the introduction and use of IS artifacts (here symbolic meaning) in societal settings. On the one hand, Shultze and Boland (2000) use Bourdieu to help understand the roles of information gatekeepers. Schultze (200la, 2001b) uses Van Maanen's (1988) notion of confessional tales to frame the narratives in her ethnographic fieldwork in a way especially attuned to Bourdieu's call for reflexivity in intensive research. On the other hand, Kvasny's research program examining the digital divide in African American communities uses Bourdieu's concepts of capital, habitus, and field as theories for understanding the IS practices of individuals, groups, and organizations. In particular, she is interested in how IT reproduces social inequality (Kvasny 2002a, 2002b; Kvasny and Keil 2003; Kvasny and Truex 2000, 2001).

To these authors, one advantage Bourdieu provides over that of other European critical social theorists such as Giddens and Habermas or over postmodern theorists like Derrida is that Bourdieu's own empirical research offers some guidance as to how to go about using his theoretical framework. Whereas Bourdieu uses empirical work to develop theory, thus making his theory more convincing and easier to apply, other social 
theorists have little to say about empirical research and methodology. Thus this French variation on critical social theory combines an interest in the practical concerns of examining social order with the more cerebral act of theorizing about that order.

In another attempt to add further empirical work inspired by Bourdieu's CST in the domain of information technologies, Helen Richardson (2003) studied customer relationship management technology utilization. Richardson, in examining social relations around CRM system use, discovered the application of symbolic violence as a mode of domination and illustrated how the relationships between agencies and structures (social and technology enforced and supported) manifest and reinforce themselves in the logic of practice.

While Bourdieu has been used on both sides of the Atlantic by IS scholars, it turns out that references to two other prominent French thinkers differ in that respect. Crozier has been essentially used by IS scholars in France, while Latour was mostly used outside of France.

\subsection{Crozier: The Uncertainty Zone Enlarged by Social Actors}

After showing that, even in bureaucracies, actors circumvent the rules and find some degree of leeway (Crozier 1963), Crozier and Friedberg (1977) tended to generalize this conduct and develop its theorizing: in order to avoid domination, actors tend to increase their "uncertainty zone" (i.e., their power to act as they want) which implies that their conduct is not totally constrained. Therefore, "power resides in the degree of leeway [freedom; marge de liberté] that each partner has in a power relationship" (Crozier and Friedberg 1977, p. 60). The circular character of this definition is noted by Caillé ("De finalitépar nature, il devient moyen de fins indéterminées," 1981). The first stake is power as the possibility of chosen action in a collective setting. But it is surprising that Caillé posits that a legitimate goal of power becomes a means servicing indeterminate ends. For in the same article, Cattlé criticizes the more substantive sociology of interest of Bourdieu. Finally, it is clear that with Bourdieu, the social actor is more structurally constrained than with Crozier. Many in the French IS literature have cited Crozier, probably because his theory provides greater openness to human agency than do the poststructuralist theories of Bourdieu, Foucault, and Giddens.

If we do the genealogy of Crozier's use in IS, its paradoxically by Peaucelle that we should begin. In fact, after a doctorate in computer science, Peaucelle spent three years with Crozier's research center. Ballé and Peaucelle (1973) then published a book, The Power of Data Processing. In his preface, Crozier (1973) writes

As with any important techno-organization innovation, computerization does not raise the problem of functioning or implementing some model, but that of change, from a socio-technical system to another one whose characteristics cannot be predicted precisely, and which in any case cannot be considered as and fully achieved, but as a stage in an evolution....The situation is generally the reverse of what is generally thought. At the beginning there are all the more many problems as participation of employees is actively searched (pp. 11-14). 
Crozier also strongly influenced Pavé who showed the utopia-due to the hyperfunctionalism of computer scientists — of firms made of transparent human relationships. He also advocated that there could not be any correspondence between computers and organizational structures because of the attitude of employees maintaining their uncertainty zone. Then Morley (1993) used these works, with the exception of Pavé, to show that the effect of participation on the complexity of projects depends on the choice of the users, the attribution of roles, and the selection of phases during which they participate. More recently Besson and Rowe (2001) sketch the role of leeway margins in the dynamics of enterprise systems projects. Many in the French IS literature have cited Crozier, probably because he opens a window for thinking action other than with the sociologists of domination (Bourdieu, Foucault, and Giddens).

\subsection{Latour and Agency: A Constructivist Ontology}

The ideas of the French sociologist and scholar of science and technology, Bruno Latour, have captured the interest of a generation of IS scholars (Baskerville and Myers 2002; Bijker 1994; Bijker and Law 1994; Walsham 1995, 1997), an assertion readily confirmed by glancing through the published proceedings of the last eight IFIP WG 8.2 transactions (Jones 2000). Much of this work utilizes Latour's actor network theory to help understand the interaction of both human actors and nonhuman actants. In studying these relationships, researchers hope to see how this interaction creates and shapes the social contexts in which the IT object exists. It is a form of evaluation of the IS artefact and its social setting. Thus one could argue that the ontology behind the relatively equal agency of any action in a network is relativistic and very socially constructivist. The network is a linguistic and relationally constructed object always in the process of being constructed. However, from an ontological point of view, this is not the end of the story with Latour, for he does not accept the dichotomous view of the reality that has inspired the previous discussion.

An underlying and critical concept in Latour's thinking, and one that set his work apart, is that he rejects the separation of the natural world from the social world, or what he terms the "modern constitution" (Latour 1993). This constitution has as its first guarantors the idea that "Nature is transcendent but mobilizable (immanent), and that Society is immanent but it infinitely surpasses us (transcendent)" (ibid, p. 141). Rather, Latour holds for a "nonmodera constitution" in which he sees the "nonseparability ofthe common production of societies and natures" (ibid,p. 141). It is an ontological blended middle ground.

\section{CONCLUSION: THE CONTRIBUTION OF FRENCH SCHOLARS TO THE QUESTION OF THE CORE OF THE IS DISCIPLINE}

If we examine the French scholars who have had some influence on IFIP 8.2 since the first Manchester conference in 1984, the scholars discussed in sections 4.1 through 4.3 have not been cited often. On the other hand, work inspired by Bourdieu has been 
present in the past three conferences. Latour's ideas have been more widely used and cited. In fact Latour was an invited plenary speaker, as well as a published author at the 1995 Cambridge WG 8.2 conference (Latour 1996).

For the moment, we suggest that one contribution of this paper is to raise these questions while highlighting the contribution of French scholars to the debate regarding one of the central objects of study in our field.

We see three contributions of French scholars to information systems and the central issue of control.

1. They help us see how central the concepts of control and evaluation are in our field.

2. To underline the major difference between a software engineering ontological view (realist) and that of a management and social scientist ontological view (be it constructivist, critical realist, pluralist, or that of Latour). By definition, the latter assesses the relevance of an information system, as an artefact, with respect to its human and organizational context and not just with respect its capabilities and specifications for some tasks (i.e., from a logical viewpoint).

3. They give some theoretical and methodological advice as to the study of the exercise of power and control through the contribution of Bourdieu, Crozier, and Latour.

In continued research we will explore the nature and influence that French thinkers and researchers have contributed both directly and indirectly to this debate.

\section{REFERENCES}

Albert, S., and Whetten, D. A. “Organizational Identity,"Research in OrganizationalBehavior (7), 1985, pp. 263-295.

Alter, S. "A General, Yet Useful theory of Information Systems," Communications ofthe AIS (1:13), 2003.

Avison, D. "The UK Information Systems Perspective: A Personal View," Systeme d'Infomation et Management (3:7), 2002, pp. 49-54.

Ballé, C., and Peaucelle, J. L. The Power ofData Processing, Paris: Editions d'organisation, 1973.

Banville, C., and Landry, M. "Can the Field of MIS Be Disciplined?," Communications of the $\operatorname{ACM}(32: 1) 1989$, pp. 48-60.

Baskerville, R. L., and Myers, M. D. "Information Systems as a Reference Discipline," MIS Quarterly (26:1), 2002, pp. 1-14.

Benbasat, I., and Zmud, R. "The Identity Crisis within the IS Discipline: Defining and Communicating the Discipline's Core Properties," MIS Quarterly (27:2), 2003, pp. 183, 193.

Besson, P., and Rowe F. "ERP Project Dynamics and Enacted Dialogue: Perceived Understanding, Perceived Leeway, and the Nature of Task-Related Conflicts," DataBase (32:4), 2001, pp. 47-66.

Bijker, W. E. "The Social Construction ofFluorescent Lighting, or How an Aircraft was Invented in its Diffusion Stage," in W. E. Bijker and J. Law (Eds.), Shaping Technology/Building Society: Studies in Sociotechnical Cambridge MA: The MIT Press, 1994, pp. 75-102.

Bijker, W. E., and Law, J. (Eds.). Shaping Technology / Building Society: Studies in Sociotechnical Change, Cambridge MA: The MIT Press, 1994.

Bourdieu, M. Le sens pratique, Paris: Editions de Minuit, 1980. 
Caillé, A. "La sociologie de l'intérêt est-elle intéressante?" Sociologie du travail (23:3), 1981, pp. 257-274.

Carr, N. "IT Doesn't Matter," Harvard Business Review, May 2003, pp. 1-10.

Crozier, M. "Le phénmomèn bureaucratique," Paris: Seuil, 1963.

Crozier, M. "Préface," in C. Ballé and J. L. Peaucelle, Le pouvoir informatique dans l'entreprise, Paris: Les Editions d'Organisation, 1973, pp. 11-19.

Crozier, M., and Friedberg, E. Actors and System: The Politics of Collective Action, Boston: Ginn and Co., 1977.

Culnan, M. J. "The Intellectual Development of Management Information Systems, 1972-1982: A Co-citation Analysis," Management Science (32:2), 1986, pp. 156-172.

Culnan, M. J., and Swanson, E. B. "Research in Management Information Systems, 1980-1984: Points of Work and Reference," MIS Quarterly (10:3), 1986, pp. 288-303.

Davis, G. B. Management Information Systems: Conceptual Foundations, Structure, and Development, New York: McGraw-Hill Book Company, 1974.

Davis, G. B., and Olson, M. H. Management Information Systems: Conceptual Foundations, Structure, and Develompent ( $2^{\text {nd }}$ ed.), New York: McGraw-Hill Book Company, 1985.

Dehaene, P. "Organization, Project and Strategy as Symbols," in Proceedings of the Third Conference Economique et Intelligence Artificielle (CECOIA III-CEMIT), Tokyo, JASMIN, Volume I, 1992, pp. 243-247.

Desq, S.; Fallery, B.; Rodhain, F.; and Reix R. "25 ans de recherches en systèmes d'informations ," Systèmes d'Information et Management (7:3), 2002, pp. 5-33.

GRASCE. Entre systémique et complexité chemin faisant: mélanges en l'honneur du Professeur Jean-Louis LeMoigne, Paris: Presses Universitaires de France, 1999.

Gray, R. "A Brief Historical Review of the Development of the Distinction Between Data and Information in the Information Systems Literature," in J. Ross and D. Galletta (Eds.), Proceedings of the $9^{\text {th }}$ Americas Conference on Information Systems, Tampa, FL, 2003, pp. 2843-2849.

Hirschheim, R., and Klein, H. K. "Crisis in the IS Field? A Critical Reflection on the State of the Discipline," Journal of the Association for Information Systems (4:5), 2003, pp. 237293.

Hirschheim, R.; Klein, H. K.; and Lyytinen, K. Information Systems Development and Data Modeling: Conceptual and Philosophical Foundations, Cambridge, England: Cambridge University Press, 1995.

Husserl, E. Idées directrices pour une phénoménologie ( $3^{\text {rd }}$ ed.), Paris: Gallimard, 1950 ( $1^{\text {st }}$ ed., 1913).

Jones, M. R. "The Moving Finger: The Use of Social Theory in WG8.2 Conference Papers, 1975-1999," in Baskerville, J. Stage, and J. I. DeGross (Eds.), Organizational and Social Perspectives on Information Technology, Boston: Kluwer Academic Publishers, 2000, pp. 15-31.

Kallinikos, J. "Reopening the Black Box of Technology: Artefacts and Human Agency," in L. Applegate, R. Galliers, and J. I. DeGross (Eds.), Proceedings of the $23^{\text {rd }}$ International Conference on Information Systems, Barcelona, Spain, 2002, pp. 287-294.

Karahanna, E.; Davis, G. B.; Mukhopadhyay, T.; Watson, R., and Weber, R. "Embarking on Information Systems' Voyage to Self-Discovery: Identifying the Core of the Discipline," Panel Presentation at the $24^{\text {th }}$ International Conference on Information Systems, Seattle, WA, 2003.

Kvasny, L. "A Conceptual Framework For Examining Digital Inequality," in R. Ramsower and J. Windsor (Eds.), Proceedings of the $8^{\text {th }}$ Americas Conference on Information Systems, Dallas, TX, August 2002a, pp. 1798-1805.

Kvasny, L. Problematizing the Digital Divide: Cultural and Social Reproduction in a Community Technology Initiative, Unpublished Ph.D. Thesis, Department of Computer Information Systems, Robinson College of Business, Georgia State University, 2002b. 
Kvasny, L., and Keil, M. "The Challenges of Redressing the Digital Divide: A Tale of Two Cities," in L. Applegate, R. Galliers, and J. I. DeGross (Eds.), Proceedings of the $\mathbf{2 3}^{\text {rd }}$ International Conference on Information Systems, Barcelona, December 2003, pp. 817-828.

Kvasny, L., and Truex, D. "Defining Away the Digital Divide: A Content Analysis of Institutional Influences on Popular Representations of Technology," in B. Fitzgerald, N. Russo, and J. I. DeGross (eds.), Realigning Research and Practice in Information Systems Development: The Social and Organizational Perspective, Boston: Kluwer Academic Publishers, 2001, pp. 399-414.

Kvasny, L., and Truex, D. "Information Technology and the Cultural Reproduction of Social Order: A Research Program," In R. Baskerville, J. Stage, and J. I. DeGross (Eds.), Organizational and Social Perspectives on Information Technology, Boston: Kluwer Academic Publishers, 2000, pp. 277-294.

Lamb, R., and Kling, R. "Reconceptualizing Users as Social Actors in Information Systems Research," MIS Quarterly (27:2), 2003, pp. 197-235.

Landry, M., and LeMoigne J. L. "Towards a Theory of Organizational Systems: A General System Perspective," in B. Gilchrist, Proceedings of the IFIP Congress '77, Amsterdam: Elsevier-Science, 1977, pp. 801-805.

Latour, B. We Never Have Been Modern (Nous n'avons jamain été modernes), C. Porter (trans), Hemel Hempstead, England: Harvester Wheatsheaf, 1993.

Latour, B. "Social Theory and the Study of Computerized Work Sites," in W. J. Orlikowski, G. Walsham, M. R. Jones, and J. I. DeGross (Eds.), Information Technology and Changes in Organizational Work, London: Chapman \& Hall, 1966, pp. 295-307.

LeMoigne, J. L. "La conception des systèmes d'information organisationnels: de l'ingénierie informatique à l'ingéniérie systémique," in J. A. Bartoli and J. L. LeMoigne (Eds.), Organisation intelligente etsystéme d'information stratégique, Paris: Economica, 1996, pp. 25-52.

LeMoigne, J. L. La Modelisation des sytèmes complexes, Paris: Dunod, 1990.

LeMoigne, J. L. La theorie du systeme general, theorie de la modelisation, Paris: Presses Universitaires de France, 1977.

LeMoigne, J. L. Les systèmes d'information dans les organisations, Paris: Presses Universitaires de France, 1973.

LeMoigne, J. L. Vers un système d'information organisationnel? Revue Française de Gestion, Novembre-Décembre, 1986, pp. 20-31.

LeMoigne, J. L., and Pascot, D. (Eds.). Les processus collectifs de mémorisation, Aix-enProvence: Librairie de l'Université d'Aix-en-rovence, 1979.

LeMoigne, J. L., and Van Gigch J. P. "The Design of an Organization Information System: Intelligent Artifact for Complex Organizations," Information and Management (19), 1990, pp. 325-331.

Marciniak, R., and Rowe F. Systèmes d'information et dynamique des organisations, Paris: Economica, 1997.

Mélèse, J. Approche systémique des organisations, Paris: Editions d'organisation, 1979.

Michaux, V., and Rowe, F., Complémentarité entre système d'information informatisé, communautés de pratiques et vigilance dans la haute fiabilité: le cas d'une compagnie d'assistance, Systèmes d'information et Management (9:1), 2004.

Monod, E. "Epistémologie de la recherche en systèmes d'information," in F. Rowe (Ed.), Faire de la recherche en systèmes d'information, Paris: Vuibert, 2002, pp. 21-56.

Morley, C. "Information Systems Development Methods and User Participation: A Contingency Approach," in D. Avison, J. E. Kendall, and J. I. DeGross (Eds.), Human, Organizational, and Social Dimensions of Information Systems Development, Amsterdam: North Holland, 1993, pp. 127-142. 
Orlikowski, W. J., and Iacono, C. S. "Research Commentary: Desperately Seeking the 'IT' in IT-A Call to Theorizing the IT Artifact," Information Systems Research (1:2), 2001, pp. 121-134.

Parsons, J., and Wand, Y. "Emancipating Instances from the Tyranny of Classes in Information Modeling," ACM Transactions on Database Systems (25:2), 2000, pp. 228-268.

Peaucelle J.-L. Les systèmes d'information - la représentation, Paris: Presses Universitaires de France, 1981.

Postman, N. Conscientious Objections: Stirring up Trouble about Language, Technology and Education, New York: Vintage Books, 1988.

Purao, S.; Rossi, M.; and Bush, A. "Towards an Understanding of the Use of Problem and Design Spaces During Object-Oriented System Development," Information and Organization (12:4), 2002.

Reix, R., and Rowe, F. "La recherche en systèmes d'information: de l'histoire au concept," in F. Rowe (Ed.), Faire de la recherche en systèmes d'information, Paris: Vuibert, 2002, pp. $1-21$.

Richardson, H. "CRM in Call Centres: The Logic of Practice," in M. Korpela, R. Montealegre, and A. Poulymenakou (Eds.), Organizational Information Systems in the Context of Globalization, Boston: Kluwer Academic Publishers, 2003, pp. 68-83.

Robey, D. "Diversity in Information Systems Research: Threat, Promise, and Responsibility," Information Systems Research (7:4), 1996, pp. 400-408.

Rolland, C. "Introduction à la conception des systèmes d'information et panorama des méthodes disponibles," Revue Génie logiciel (4), June, 1986, pp. 7-62.

Rowe, F,, and Struck, D. "Cultural Values, Media Richness and Telecommunication Use in an Organization," Accounting, Management and Information Technologies (9:3), 1999, pp. $161-92$.

Saga, V., and Zmudm R. "The Nature and Determinants of Information Technology Acceptance, Routinization and Infusion," in L. Levine (Ed.), Diffusion, Transfer and Implementation of Information Technology, Amsterdam: North-Holland, 1994, pp. 67-86.

Sartre J.-P. L'être et le néant: essai d'ontologie phénoménologique, Paris: Gallimard, 1943.

Sawyer, S., and Chen, T. "Conceptualizing Information Technology in the Study of Information Systems: Trends and Issues," in E. Wynn, E. R. Whitley, M. Myers, and J. I. DeGross (Eds.), Global and Organizational Discourse About Information Technology, Boston: Kluwer Academic Publishers, 2002, pp. 109-131.

Schultze, U. "A Confessional Account of an Ethnography about Knowledge Work," MIS Quarterly (23:1), 2001 a, pp. 1-39.

Schultze, U. "Reflexive Ethnography in Information Systems Research," in E. Trauth (Ed.), Qualitative Research in IS: Issues and Trends, Hershey, PA: Idea Group, 2001b, pp. 78103.

Schultze, U., and Boland Jr., R. J. "Knowledge Management Technology and the Reproduction of Knowledge Wwork Practices," Journal of Strategic Information Systems (9), 2000, pp. 193-212.

Shapiro, S. "Places and Spaces: The Historical Interaction of Technology, Home, and Privacy," The Information Society (14), 1998, pp. 275-284.

Soh, C., and Markus L. "How IT Creates Business Value: A Process Theory Synthesis," in J. I. DeGross, G. Ariav, C. Beath, R. Hoyer, and C. Kemerer (Eds.), Proceedings of the Sixteenth International Conference on Information Systems, Amsterdam: Amsterdam, The Netherlands, 1985, pp. 29-41.

Tabourier Y. De l'autre côté de MERISE, Paris: Editions d'Organisation, 1986.

Van Maanen. J. Tales from the Field: On Writing Ethnography, Chicago: University of Chicago Press, 1988. 
Walsham, G. "Actor Network Theory and IS Research,” in A. S. Lee, J. Liebenau, and J. I. DeGross (Eds.), Information Systems and Qualitative, London: Chapman \& Hall, 1997, pp. 446-480.

Walsham, G. "The Emergence of Interpretivism in IS Research," Information Systems Research (6:4), 1995, pp. 376-394.

Weber, R. "Editors Comments: Theoretically Speaking," MIS Quarterly (27:3), 2003, pp. iiixiii.

Weber, R. "Towards a Theory of Artifacts: A Paradigmatic Base for Information Systems Research," Journal of Information Systems, Spring 1987, pp. 3-19.

Willcocks, L., and Lester, S. "How Do Organizations Evaluate and Control Information Systems Investments? Recent UK Survey Evidence," in D. Avison, J. E. Kendall, and J. I. DeGross (Eds.), Human, Organizational, and Social Dimensions of Information Systems Development, Amsterdam: North-Holland, 1993, pp. 15-40.

Wilensky, R. Planning and Understanding: A Computational Approach to Human Reasoning, Reading, MA: Addison Wesley, 1983.

\section{ABOUT THE AUTHORS}

Frantz Rowe is a professor in Information Systems at the University of Nantes. He has an MA in Economics and an ME in Civil Engineering from the University of Lyon, an MS from the University of California, Berkeley, and a Ph.D. from the University of Paris in Information Systems. He cofounded the French Association in Information Systems in 1991 and was appointed Editor in Chief of Systemes d'Information et Management in 1996. With the support of the National Foundation for Management (FNEGE in French), he edited a book, Doing Research in IS, in 2002. His research interests include the transformations of work and organizations linked to DSS, new media and in particular to the integration ofenterprise systems. He can be reached at frantz.rowe@sc-eco.univ-nantes.fr.

Duane Truex researches the social impacts of information systems and emergent ISD. He is an associate editor for the Information Systems Journal, has coedited two special issues of The Database for Advances in Information Systems, and is on the editorial board of the Scandinavian Journal of Information Systems, the Journal of Communication, Information Technology \& Work, and the Online Journal ofInternational Case Analysis. His work has been published in Communications of the ACM, Accounting Management and Information Technologies, The Database for Advances in Information Systems, European Journal of Information Systems, le journal de la Societé d'Information et Management, Information Systems Journal, Journal of Arts Management andLaw, IEEE Transactions on Engineering Management, and 40 assorted IFIP transactions, edited books, and conference proceedings. He is a member of the Decision Sciences and Information Systems faculty in the Chapman Graduate School, College ofBusiness, at Florida International University, and is an associate professor on leave from the Computer Information Systems Department, Robinson College of Business, at Georgia State University. He can be reached at duane.truex@fiu.edu

Lynette Kvasny is an assistant professor of Information Sciences and Technology at the Pennsylvania State University. She received her Ph.D. from the Department of Computer Information Systems at Georgia State University, Robinson College ofBusiness in Atlanta. Her research focuses on the appropriation of information and communication technology by historically underserved groups and institutions. Her research has appeared in The Data Base for Advances in Information Systems, the proceedings of IFIP Working Group 8.2 conferences, and the the proceedings of the International Conference on Information Systems. Her research is funded by a Faculty Early Career Development Grant from the National Science Foundation. Kvasny can be reached at lkvasny@ist.psu.edu. 